\title{
THE SEVENTH INTERNATIONAL CONGRESS ON RHEUMATIC DISEASES
}

In 1940 it had been planned to hold a Congress of the Ligue Internationale contre le Rhumatisme in America, but this had to be cancelled because of the war. In 1945 there were rumours of an important Congress to be organized in the U.S.A. in 1948 or 1949, and by 1946 the late Professor Ralph Pemberton was hard at work making preparations for this event. His unceasing efforts on behalf of this Congress contributed largely to his death. In January, 1947, the first official invitation was circulated by Dr. Richard Freyberg, on behalf of the American Rheumatic Association, asking members of the Ligue to be their guests at this Seventh International Congress to be held in America in 1949, and in 1948 Dr. Philip Hench himself did a tour of this country and the continent, collecting views and disseminating information about the Congress.

These tremendous preparations augured well, but, those of us who have attended a number of such meetings elsewhere, had our greatest expectations surpassed by the success of this one. The American hospitality and forethought came well up to its famed standard; the delegation from overseas exceeded all estimates, twenty-six different countries being represented, the list being topped by Great Britain and Canada with twenty-nine and twentyeight delegates respectively.

The high spot of the Congress was, however, the quality of the hundred papers presented. They covered the whole field of rheumatology but especially stressed the fundamentals of morbid histology, histochemistry, and above all endocrinology. The first international presentation of the work of Hench, Kendall; Slocumb, and Polley of the Mayo Clinic, of Bauer and Thorn of Boston, and Woolfson of Chicago on this latter aspect was of such interest that, to quote Hench in lighter vein, the discussion took the lines of "rheumocrinology ".

After the main meeting at New York, a postconvention tour was organized to take in the American Medical Association meeting at Atlantic City, and research centres and hospitals at Philadelphia, . Boston, Buffalo, Chicago, Detroit, the Mayo Clinic, Washington, Toronto, and Montreal, and here ample opportunity was afforded to see the background of much of the work discussed at New
York and in particular the treatment of rheumatic cases with Cortisone and ACTH.

The impression gained by many of us was of the vast strides recently made to put rheumatology on a sound academic footing and of the vast sums being spent, especially in America, on both research and treatment of the rheumatic diseases. The Cinderella of "medicine had met her Prince Charming.

This did not, however, apply to America only, as excellent work was being done at numerous centres on the Continent, though, perhaps with the exception of Denmark and Sweden, the economic difficulties were hampering their efforts to some extent.

During the course of the Conference, and during the succeeding days, many useful and important discussions took place on the endocrinological and histological aspects of rheumatism. In addition to an elaboration of the work already published on the benefit of the corticotrophic hormone of the pituitary and of Compound $\mathrm{E}$ on the collagen group of diseases (rheumatoid arthritis, spondylitis rheumatic fever, dermatomyositis, erythema nodosum and lupus erythematosus generalizatia), interesting data were forthcoming on their effect on gout, and also on the control of a hereditary tendency to hyperuricaemia by an abnormal cortical androgen in this disease.

The morbid histology usually seen in rheumatoid disease was generally considered to be nonspecific but discoverable more commonly and more widely in this disease than in any other condition.

New evidence was produced on hereditary factors in rheumatoidaarthritis, spondylitis, and gout, but the old dispute on the relationship between rheumatoid disease and ankylosing spondylitis remained undecided. In the practical sphere the value of pre- and postoperative treatment in orthopaedics, and especially in Smith-Petersen's cup arthroplasty, was strikingly demonstrated. '

Short summaries of twenty-eight of the papers given in New York are included in this number: ; they form a résumé of some of the important work discussed, and may act as an easy reference in future years, when the Proceedings of the Congress, shortly to be published, will be available for consultation of the papers in full.

We are indebted to Messrs. W. B. Saunders and 
Co., of Philadelphia, for permission to publish the summaries of the Congress. Many of these papers will be published in full in the Proceedings.

A few papers, for instance one from the Mayo Clinic on Compound E, one by Forestier on copper, and those from Bath on the histology of rheumatoid disease, have already appeared in the Annals in full and are therefore not included among the summaries.

In conclusion we cannot do more than wish the European and Pan-American Congresses of 1951, to be held respectively in Spain and the U.S.A., and the Joint International Congress of 1953 arranged for Switzerland, the same measure of success as this Seventh Meeting recently held in New York.

\section{The Histophysiology of the Connective Tissues}

\section{S. H. BENSLEY and A. W. HAM* Toronto, Canada}

The four primary tissues of the body represent structural specializations for the performance of certain functions. Connective tissue is specialized to play a supporting and nutritive role under conditions of health, and a defensive one under conditions of infection. To provide proper support in the body requires that connective tissues contain a high proportion of intercellular substances, for these non-living materials are much stronger than living cells.

The nutritive role of connective tissue is determined by the fact that the blood and lymph vessels of the body are all confined to it. Since most cells do not abut on capillaries they must be nourished from the connective tissue that separates them from capillaries. This is usually explained by postulating that connective tissue so disposed, is bathed in tissue fluid that emerges from capillaries as a dialysate of blood plasma and is returned to the circulatory system by both the blood and lymph capillaries of connective tissue.

In playing a defensive role connective tissue serves as the "arena of inflammation ". In addition to vascular and specific cellular activities associated with the inflammatory process the intercellular substances of connective tissue may act as a barrier to the spread of infection.

Morphologically two main types of intercellular substances can be identified in connective tissue: (1) a formed type (reticular, collagenic, and elastic fibres), and (2) an amorphous type (ground and cement substances-mucopolysaccharides). Representatives of both main types are present in most kinds of connective tissue but their proportions are different in the different subtypes of connective tissue.

A comparison of the microscopic structure of, and mechanism for nutrition in (1) mesenchyme, (2) cartilage, (3) bone, and (4) synovial membranes and joint capsules,

* From the Department of Anatomy, University of Toronto, Toronto, Canada. shows that the tissue fluid concept cannot fully account for nutrition in and through all types of connective tissue. The amorphous intercellular substances appear to be specialized for permitting nutritive diffusion phenomena to operate between capillaries and cells. The formed types of intercellular substances on the other hand are specialized chiefly for support.

Evidence obtained from the study of normal development and repair phenomena suggests that the degree to which fibroblasts are differentiated is related to whether they produce amorphous or formed types of intercellular substance.

The Pathological Distinction between Osteo-Arthritis and Osteophytosis of the Spine

DOUGLAS H. COLLINS

Leeds, England.

Osteo-arthritis is the name for a condition which can only affect synovial (diarthrodial) joints. It is a sequence of morbid changes originating in destruction or degeneration of articular hyaline cartilage. Marginal hyperplasia of bone is only one of its later manifestations, and its earliest stages, when cartilage alone is principally affected, are not detectable either radiologically or by the examination of macerated anatomical specimens. The condition affects groups of, or isolated synovial joints of the vertebral column (apophysial and costovertebral), and is not necessarily associated with marginal lipping of the vertebral bodies. The latter condition (osteophytosis, or spondylosis deformans) is a consequence of collapse, degeneration, or distortion of one or more intervertebral disks, and the diarthroses between the corresponding segments of the spine may be normal. As long ago as 1897 Benecke related marginal lipping with disorder of the intervertebral disks, a view also held by Schmorl.

The mode of origin of osteophytes of the vertebral bodies has been studied by dissection and histological preparations. Osteophytes cannot form so long as the nucleus pulposus is intact and turgid and the vertebral bodies are normally separated. Collapse of the disk leads to slight forward tilting of the vertebrae and the forward extrusion of what plastic disk substance remains. The periosteum is stripped off the vertebral body on either side of this extruded disk substance, and the osteophytes subsequently develop in and take the form of the area of periosteal elevation. The new bone is typical of reactive bone formed beneath periosteum, and is at first more or less compact. The anterior common ligament prevents the extrusion of disk substance in the mid-line, and this explains the usual absence of osteophytes in this situation. Osteophytes are produced by a similar mechanism in the concavities of a scoliosis. The apophysial joints corresponding to grossly lipped vertebral bodies have been examined histologically and have often shown either healthy or slightly atrophic cartilage but no osteo-arthritis.

Distinction between osteo-arthritis and osteophytosis of the spine may help to clarify the clinical analysis of a difficult group of painful diseases of the spine. The 
recognition of an osteo-arthritis of the posterior intervertebral joints occurring independently of radiological evidence of osteophytosis may prove of importance in this connexion.

\section{Diagnosis of Osteo-Arthritis \\ AUGUSTUS M. DAVISON* \\ Hot Springs, National Park, A'rkansas}

The criteria for making a diagnosis of osteo-arthritis vary, and there is much disagreement among doctors as to what symptoms may be attributed to this disease, especially where compensation is involved. The term osteo-arthritis should represent a distinct clinical disease with appropriate symptomatology, not simply a radiological diagnosis. It is suggested that the confusion would be resolved by adherence to a clear definition setting up certain requirements. Localized symptoms of pain and perhaps limitation of motion following a benign and remittent course are appropriate to the disease. Radiographs should confirm pathological alteration at the site. The exact aetiology remains undetermined. These criteria would eliminate those patients with pre-symptomatic $x$-ray changes, those demonstrating physiologic ageing of the joints, and those with hypertrophic changes secondary to a known cause. The diagnosis would be reserved for those patients demonstrating symptomatic and pathologic idiopathic degenerative joint disease. Since the process is recognized as a local tissue change, only the one or few proven joints should be mentioned in a diagnosis. The term "generalized" osteo-arthritis is inacceptable.

\section{The Histopathology of the Neuromuscular System in Rheumatoid Arthritis \\ L. RAYMOND MORRISON, PEDRO M. CATOGGIO, and WALTER BAUER \\ Boston, Massachusetts}

Peripheral nerves or muscles or both from eighty cases of rheumatoid arthritis were histologically examined. Thirty were biopsies of muscle only. In addition the spinal cord was examined in most of the autopsy cases, and in some instances the sympathetic ganglia were also studied.

It was found that small paravascular foci of round cells were present in the interstitial tissue of the nerves and muscles. These foci were usually in the perineurium or perimysium, but were sometimes found in other sheaths as well. The sympathetic chain was similarly affected by cellular infiltrations, not only along the course of the fibres but also within the capsule of the ganglia. About 75 per cent. of the nerves and 65 per cent. of the muscles had these cellular accumulations. Foci were found in the muscles whether blocks were taken from extensors or flexors, from the belly or near the tendon, from close to or far from an involved joint, from atrophied or healthy muscle. Lesions were also

* Chief, Rheumatic Diseases Section, Army and Navy General Hospital. widely distributed in nerves, whether motor, sensory or mixed. There was not much relationship between the presence of cellular accumulations on the one hand, and clinical activity of the disease, the age of the patient, and the duration of the disease on the other.

In addition there were in some cases slight alterations in the myelin sheath and axones of the peripheral nerves, with retrograde degeneration of the anterior horn cells of the spinal cord. These anterior horn cell changes were greater than the ordinary changes due to advancing age.

After these nodular foci of round cells had been compared with those found in other diseases of the connective-tissue group, such as lupus erythematosus disseminatus, dermatomyositis, and rheumatic heart disease, it was concluded that no distinguishing diagnostic differences could be relied upon because the appearances in the various diseases were often similar.

\section{The Peripheral Genesis of Pain}

$$
\begin{gathered}
\text { J. H. KELLGREN } \\
\text { Manchester, England }
\end{gathered}
$$

There are several factors involved in the peripheral production of pain in disease.

In some forms of cutaneous hyperalgesia (erythralgia) warming the part in the range $30^{\circ}$ to $45^{\circ} \mathrm{C}$. $\left(86^{\circ}\right.$ to $115^{\circ} \mathrm{F}$.) causes spontaneous skin pain, while with deep hyperalgesia cooling the part in the range $30^{\circ}$ to $15^{\circ} \mathrm{C}$ $\left(86^{\circ}\right.$ to $59^{\circ} \mathrm{F}$.) causes spontaneous deep pain. These temperature effects are most easily demonstrated with the circulation occluded and are, therefore, due to the temperature change as such and not to secondary changes of circulation.

The effect of arterial occlusion and venous engorgement has been studied in a variety of painful conditions. At least three patterns of response occur: (a) no effect, found in painful conditions due to morphological changes in the pain receptors and fibres and also in some forms of arthritis; (b) dramatic increase of pain during arterial occlusion, found in abscesses and operation wounds and in some other inflammatory conditions ; (c) increase of pain with venous congestion, often combined with a modified increase during arterial occlusion, found in a variety of inflammatory posttraumatic and arthritic conditions.

Various chemical solutions produce different results when injected into the deep tissues. Thus osmotic changes (hypertonic solution) cause a short wave of spontaneous pain only. Alterations of $p \mathrm{H}$, particularly acids, cause immediate pain and prolonged hyperalgesia. Alterations of the concentration of particular ions cause various responses; thus $\mathrm{KCl}$ causes immediate pain and hyperalgesia, while $\mathrm{CaCl}_{2}$ causes no immediate pain but delayed long lasting hyperalgesia.

Hyperalgesia to mechanical, thermal, and possibly chemical stimuli is an important factor in the production of pain, but there are probably many different mechanisms involved in the production of pain in disease. In conditions which give an increase of pain during arterial occlusion, such as the inflammatory and post-traumatic 
states, measures designed to increase the local circulation relieve pain, but when the circulatory tests are negative as in painful states due to morphological changes in the nerves, and in most rheumatic conditions, increasing the local circulation is of little value, though some temporary relief may be obtained from warmth through the effect of temperature on deep pain. More accurate knowledge of the mechanism involved in the peripheral genesis of pain is required if we are to treat pain intelligently by medical, surgical, or physiotherapeutic procedures.

\section{Diseases Arising from Overstrain and Wear and Tear on the Muscles of the Skeletal System, often concealed Behind the Diagnosis of Neurosis and Rheumatism}

HENRIK SEYFFARTH and KIRSTEN MøINICHEN

$$
\text { Oslo, Norway }
$$

Emotional or affective pain occurs because emotions normally increase pain and feeling of fatigue and induce muscular tension, which in itself may call forth pain in tender muscles, tendon attachments, and joints. Anxiety tension finds expression mainly in a fixation of the thorax in the inspiration position, with drawn-up shoulders. The best treatment for neuroses has proved to be relaxation gymnastics, to teach the patient to relax during work and to release the fixed mechanism of respiration. By such daily gymnastic exercises, and training in the proper manner of working with least possible tension, it has been found possible practically to eradicate functional diseases in the musculo-skeletal system as a cause of industrial absenteeism, whereas in 1944,25 per cent. of the absenteeism was due to overstraining the neck and arms.

The Effect of $د-5$-Pregnenolone on Urinary 17-Ketosteroid Excretion and Symptomatology of Ankylosing Spondylarthritis; a Preliminary Report

ROLAND A. DAVISON and PETER KOETZ*

\section{San Francisco, California}

Increased urinary excretion of 17-ketosteroids has been demonstrated in ankylosing spondylarthritis (MarieStrümpell disease). It is observed in both male and female patients, and is present in early cases with little demonstrable joint change as well as in those patients who have had the disease for many years and show the typical findings of the advanced case.

$\Delta$-5-Pregnenolone is a steroid having several actions not characteristic of other steroids. Its chemical composition makes it a logical process material to act as a precursor of many active steroids. When normal individuals are subjected to acute stress and fatigue, adrenal cortical activity is accelerated and increased rates of 17-ketosteroid excretion are gbserved. Pregnenolone administered under such conditions lowers the 17-ketosteroid excretion, improves performance, and combats fatigue. This steroid has not to our knowledge

* From the Departments of Medicine, and Obstetrics and Gynaecology, Stanford University School of Medicine, San Francisco California. been used in disease states. Its general properties, freedom from toxicity, and ability to lower urinary 17-ketosteroid excretion and to combat fatigue suggested to one of us possible value in spondylarthritis.

$\Delta$-5-Pregnenolone acetate in vegetable oil was administered by intramuscular injection in daily dosage of 50 to $150 \mathrm{mg}$. to patients with active spondylarthritis. Urinary 17-ketosteroid excretion was studied before and during the course of administration of pregnenolone.

Total ketosteroids were measured by extraction of hydrolysed urine with carbon tetrachloride and application of the Zimmermann colour reaction.

Pregnenolone reduced the excretion of 17-ketosteroids in the urine of these patients to normal levels. Accompanying the reduction of 17-ketosteroids, there is striking relief of symptoms and objective signs of the disease. When placebo injection is substituted for the pregnenolone, the ketosteroid excretion increases and the patient regresses. Re-institution of treatment again reduces urinary 17-ketosteroid output, this being accompanied by relief of symptoms. Pregnenolone therapy does not prevent the usual rise in ketosteroid output which results from radiography.

The striking clinical improvement which accompanies the reduction in ketosteroid excretion suggests relationship between the ketosteroid excretion and clinical findings, though not necessarily a causal relationship.

Synthetic Oestrogens in the Treatment of Ankylosing Spondylitis

F. COSTE and S. BONFILS

\section{Paris, France}

Of twenty-three men with ankylosing spondylitis treated with synthetic oestrogens, thirteen obtained definite and lasting improvement in flexibility of the spine. Diethylstilboestrol was usually employed, sometimes by mouth but more often parenterally to diminish gastro-intestinal disturbances. Preliminary test-treatment with $20 \mathrm{mg}$. daily intramuscularly is carried out for two weeks. If this is well tolerated and followed by improvement, implantation of 200 to $300 \mathrm{mg}$. pellets is performed, renewed in six to twelve months. Hexoestrol and dienoestrol, used in a few cases, are much less active than stilboestrol. At present the authors are frequently using doisynolic acid, which is also less active than stilboestrol, but better tolerated.

Except for intolerance to the drug, untoward effects of treatment consist of sexual impotence and painful swelling of the breasts. When these sexual manifestations do not occur, generally no therapeutic effect is obtained. Most patients readily accept these inconveniences, happy to be relieved of pain and to feel their spines becoming more supple. In three cases oestrogen therapy was followed by aggravation of symptoms; in one of these parenteral testosterone resulted in marked improvement.

The sedimentation rate usually decreases after oestrogen therapy, but similar lowering of the sedimentation rate has been observed after oestrogen 
dministration, independent of any action on an infiammatory process.

\section{The Synovial Membrane in Osteo-Arthritis}

\section{R. E. GHORMLEY and J. R. BATEMAN \\ Rochester, Minnesota}

There are many changes found in the synovial membranes in the cases of osteo-arthritis; there is no consistently characteristic type of membrane. Fibrosis, perivascular fibrosis, vascular thickening, haemorrhage, round-cell infiltration and hyalinization, all are found; but none in a high enough percentage of cases to make us feel that the synovial reaction is the primary reaction in cases of osteo-arthritis. An attempt has been made to correlate the changes found in the membranes with those found clinically, but the very fact that no characteristic picture is found makes us believe that the synovial changes are secondary to other changes in the joint degeneration characteristic of osteo-arthritis.

The Range of Pathological Reactions which can be Displayed by Human Synovial Tissues

$$
\begin{aligned}
& \text { DOUGLAS H. COLLINS } \\
& \text { Leeds, England }
\end{aligned}
$$

Observations based on histological study of 250 synovial membranes have been collated under heads: (1) changes in synovial cells, (2) vascular and exudative phenomena, (3) leucocytic reaction.

(1) Synovial tissues are mesenchymal and display many of the same fundamental reactions as simple connective tissues elsewhere, e.g. atrophy, hyperplasia, degenerations and mutations. Particular properties of. synovial cells are the production of extra-cellular mucin, histiocyte differentiation, and the ability to form endothelial-like surfaces. These properties can occasionally be shown by extra-articular connective tissues, but the study of synovial neoplasms suggests that they may be inherent qualities of joint tissues.

(2) The rich capillary vasculature of synovial membrane is only revealed in hyperaemia. The loose-textured tissue and the synovial sac are easily and quickly distended by transudate or exudate. Vascular and exudative phenomena seemingly develop out of proportion to the severity of the inflammatory stimulus and are rarely localized to one part of the membrane.

(3) Normal synovial tissues contain very few leucocytes. Light perivascular lymphocytic diffusion is an carly reaction to traumatic and other forms of synovitis. Discrete perivascular foci are the maximal reaction seen in chronic trauma and osteo-arthritis. Great numbers of lymphocytes are seen only in severe and chronic inflammations, e.g. tuberculous and rheumatoid arthritis, or together with neutrophils in subacute suppurative synovitis. Very large lymphoid foci and follicles seem to occur only in chronic progressive (rheumatoid) arthritis, where there is also synovial proliferation. Plasma cells may replace lymphocytes. Eosinophil infiltration is rare. Neutrophils predominate in pyogenic infections but are also present in rheumatoid and rheumatic fever arthritis.

Rheumatic fever synovitis is characterized by hyperaemia, oedema, fibrinous exudate, focal fibrinoid necrosis, neutrophil reaction, and little proliferation. The rheumatoid lesion has affinities with subacute or chronic bacterial arthritis but also shows features of its own. Histological diagnosis of rheumatoid arthritis is justified, but aetiological deductions are still speculative and can be made only by analogy. While comparisons are valid between different synovial lesions in man, caution is needed in comparing reactions in synovial and extra-articular tissues, and in applying to man the results of experiments on small animals.

\section{Changes in the Skeletal Muscle of Patients with Rheumatic and Non-rheumatic Disease}

JOSEPH J. BUNIM, LEON SOKOLOFF, EDWARD J. BIEN, SIGMUND L. WILENS, MORRIS ZIFF and CURRIER MCEWEN*

$$
\text { New York }
$$

In 1945 Hugo Freund and Gabriel Steiner reported the presence of nodules of lymphocytes and plasma cells in the skeletal muscle of 100 per cent. of patients with rheumatoid arthritis and it was concluded that this lesion was specific for rheumatoid arthritis.

One purpose of our study was to determine the incidence of this cellular infiltrate in the skeletal muscle of : (a) normal persons, (b) patients with rheumatoid arthritis, (c) arthritis of types other than rheumatoid, and (d) patients with non-arthritic diseases. Another purpose was to determine whether the presence of cellular aggregates or muscle atrophy was associated with a significant change in the chemical composition of the muscle. Muscle was examined by biopsy from 202 persons, including 13 normal volunteers, 57 patients with rheumatoid arthritis, 10 with rheumatoid spondylitis (Marie-Strümpell), 21 with active rheumatic fever, 11 with inactive rheumatic heart disease, 19 with degenerative joint disease (osteo-arthritis), 10 with tuberculous arthritis, 8 with gout, and 53 with other diseases. Approximately $\mathbf{4 0 0}$ serial sections were made from each biopsy, and every fifth section was studied.

Lesions similar to those described by Freund and Steiner were found in 56 per cent. of patients with rheumatoid arthritis. Lesions indistinguishable from these, however, were found in three of the thirteen normal persons and in some patients with rheumatoid spondylitis, rheumatic fever, osteo-arthritis, tuberculous arthritis, gout, and subacute bacterial endocarditis, and also in several other diseases. These observations indicate that the muscle nodule described in rheumatoid arthritis is non-specific and probably of no diagnostic value.

Muscle samples obtained by biopsy from forty patients, including thirteen normal controls, were analysed for their contents of water, total protein, non-protein nitrogen, myosin, collagen, and adenosine-triphosphatase activity of the myosin. In patients with atrophy

\footnotetext{
* New York University, Bellevue Medical Centre.
} 
associated with various types of arthritis or with simple disuse, there were significant changes in muscle composition which included: (1) decrease in percentage of myosin and diminution of the adenosine-triphosphatase activity of the myosin; (2) fall in total protein content; and (3) absence of significant change in the average content of collagen. The changes in chemical composition correlated well with changes observed by histological study of sections simultaneously made from muscle samples analysed.

\section{The Effect of Endocrines on Articular Tissues and their Relation to Ageing Processes}

\section{MARTIN SILBERBERG and RUTH SILBERBERG*}

Growth processes and regressive changes occur spontaneously in the articular tissues of ageing mice. The changes manifest themselves in hyperplasia and hypertrophy as well as in destruction of the articular cartilage, outgrowth of bone, swelling of fibrinoid change of the interstitial substance of the ligaments, mucoid change or proliferation of the synovialis, and fibrosis of the bone marrow. These age changes differ in different strains of mice; they are genetically determined as to their onset, incidence, and severity, and are controlled by endocrine secretions. Moreover, the course of these age changes may be influenced by nutritional factors.

Administration of thyroid or sex hormones delays the time of appearance of the age changes in the articular tissues and decreases their incidence. Conversely, joint lesions can be produced in laboratory animals by the administration of anterior hypophyseal hormone or by removal of the sex glands. The changes thus produced are morphologically indistinguishable from those occurring spontaneously, although the former appear at an earlier age and are more frequent than the latter. The susceptibility to and the severity of these articular lesions may be decreased by caloric restriction and increased by feeding a high fat diet.

The findings in animals are comparable to those occurring in man as exemplified by material obtained from two cases of acromegaly and of four hundred human necropsies.

Osteo-arthritis is considered to be the result of the interaction of a tissue factor and a stimulus. The incidence, severity, and time of onset of degenerative joint disease depends on the relative intensity of these interacting principles. The tissue factor, manifesting itself in susceptibility to the disease, is controlled by such conditions as the genetic constitution of the individual, endocrine secretions, chronological age, and local blood and nerve supply. Stimuli may be of a mechanical, hormonal, or nutritional nature. The role of the endocrines in osteo-arthritis may then be twofold: the endocrines may, by accelerating ageing processes, alter the susceptibility of the cartilage to injurious agents ; or they may, in cases of endocrine disease, act as stimulating factors.

- Snodgras Laboratory of Pathology, City Hospital and Department of Pathology, Washington University School of Medicine.
Studies on the Possible Relationship of Pituitary-Adrenal Function to Arthritis

GEORGE W. THORN, PETER H. FORSHAM, JOSEPH E. WARREN, and THEODORE B. BAYLES

\section{Boston, Massachusetts}

In both normal subjects and in patients with rheumatoid arthritis, pituitary adrenocorticotrophic hormone stimulates the secretion of electrolyte-regulating, carbohydrate-regulating and androgenic adrenal steroids. A fall in the level of circulating eosinophils (direct determination) and an increase in the urinary excretion of uric acid represent sensitive indicators of the increased secretion of 11-oxy adrenal steroids. A marked increase occurs in the output of 17-ketosteroids in the urine; these are the excretory product of the increased production of androgenic adrenal steroids. Using the eosinophil change as a reflection of adrenal cortical function, we have investigated patients with rheumatoid arthritis, rheumatic fever, and gout by administering pituitary adrenocorticotrophic hormone. In selected subjects the initial eosinophil level provides a simple measure of adrenal cortical activity. Epinephrine was used to stimulate the pituitary-adrenal axis, and it produced a marked fall in circulating eosinophils and an increase in the excretion of 17-ketosteroids; but the anti-rheumatic effect was not produced, probably because of inadequate adrenal cortex stimulation.

The results of successful temporary treatment of patients with rheumatoid arthritis and rheumatic fever and gout by adrenocorticotrophic hormone confirmed the work of others. Data presented tended to show that patients with rheumatoid arthritis responded normally to epinephrine and adrenocorticotrophic hormone, and a provable adrenal insufficiency was not found. Of particular interest is the fact that the pituitary-adrenal system serves as a possible link between the effect of psychological and emotional factors on the measurable changes in vital metabolic processes.

The mechanism by which abnormally large amounts of adrenal cortical carbohydrate-regulating hormones alters the rheumatic process remains a subject for further work.

\section{Chronic Polyarthritis and Psoriasis}

$$
\begin{aligned}
& \text { P. Barcelo, E. Batalla, J. PINOL, and J. Rotes } \\
& \text { Barcelona, Spain }
\end{aligned}
$$

It appears from studies made at the Rheumatology and Dermatology departments of the Medical Clinics of the Medical Faculty of Barcelona, that the incidence of arthropathia psoriatica is very small, only about one-half of 1 per cent. of the patients seen in the rheumatological department presenting this disease. Almost uniformly the skin manifestations preceded the articular ones, in some cases by several years.

Though they seem to be more resistant to therapy, the skin lesions are no different, from the clinical and histological standpoint, from those seen in uncomplicated psoriasis. They occur most often in the scalp, trunk, elbows, and nails, in that order of frequency. The location 
of the lesions in the distal interphalangeal joints, though more frequent than in other arthritides, is neither constant nor early. Vertebral localization is relatively frequent.

Periosteal reactions of the diaphysis, especially in the distal phalanges, are much more frequent than in rheumatoid arthritis; sometimes osteolytic mutilating lesions are seen in these locations. When the process is centred in the vertebral column, lesions similar to those seen in rheumatoid spondylitis are observed, with the exception that ligamentous calcification is exceptional.

We believe that the association of arthritis and psoriasis is rare and occasional.

Psoriasis and Arthritis : a Clinical Study of 115 Cases

JOSE M. POAL, RUSSELL L. CECIL and W. H. KAMMERER New York

Over a period of approximately twenty years, 115 patients with psoriasis and arthritis have been observed in the arthritis clinics of the New York Hospital and the Hospital for Special Surgery, and in private practice. This constitutes the largest series of cases reported to date. Most cases were of typical rheumatoid arthritis. A certain number, however, differed from the classical picture in that the terminal phalangeal joints of the fingers and/or toes were involved, with and without involvement of other peripheral joints.

Resection Angulation Operation for Arthritis of the Hip HENRY MILCH

New York

The treatment of arthritis of the hip presents one of the many still unsolved problems of medicine. Until the rheumatologist discovers a specific cure for the disease, the painful, deformed hip with limited or absent motion must continue to be treated surgically.

In the past many types of arthrodesis which seemed to offer relatively simple means of treatment of the painful hip have been devised. Increasing experience has, however, demonstrated that in over 30 per cent. of the successfully fused cases, whether young or old, intractable pain in the lumbar region is a sequel of the hip fusion.

More recently, a great variety of arthroplastic operations have been described for the release of already stiffened hips. Here, too, experience has unfortunately demonstrated the relative inadequacy of this approach to the problem.

To avoid the reproaches inherent in both these types of procedure, a method has been devised which is based on the concept that the criteria of successful therapy are kinesiological and not anatomical. In principle, the operation is a combination of two earlier, well tried procedures: (1) excision of the femoral head and neck to restore mobility, and (2) angulation osteotomy in the coronal plane (Schanz type) to re-establish stability.

Through a lateral ilio-femoral incision (Watson-Jones) the capsule of the hip is exposed and opened. The femoral neck is transected at its base and the head and neck are removed en masse. Following this, the lateral aspect of the femur is subperiosteally exposed and a subtrochanteric osteotomy is performed. The lower fragment is abducted until the angle it makes with the upper fragment is congruent with the inclination of the wall of the levelled pelvis on the same side. The fragments are fixed by means of an angulated nail so that early motion can be instituted. A simple internal rotation splint is used to prevent external rotation of the thigh.

The operative intervention is exceedingly simple. It is accompanied by relatively little shock and may, therefore, be indicated in older patients. No plaster immobilization is used and the patient may consequently be allowed out of bed, walking with the aid of crutches within three to six weeks after operation. No stiffness of the knee and ankle has been observed.

Originally performed in two stages, the earlier operation has been completely revised, and since 1946 has been completed at a single sitting. It has been employed in about twenty cases of hip joint disability following upper femoral epiphyseolysis, tuberculosis, MarieStrümpell's disease, old pyogenic infection, old congenital dislocations, and fractures of the femoral neck with avascular necrosis or arthritis, in advanced osteoarthritis; and in two cases in which previous arthroplasties had been unsuccessful. In all cases it was possible to restore stability and mobility, provided the motor power of the hip muscles was adequate. In several cases some pain has persisted. In one case this was overcome by the resection of the obturator nerve, in two others by removal of the projecting screws. On the whole the patients have been satisfied and the results have been sufficiently encouraging to warrant wider use of the method.

\section{Pathological Anatomy of Collagen Diseases}

PAUL KLEMPERER*

$$
\text { New York }
$$

At present the term " collagen disease" refers to a group of clinically heterogeneous, symptomatically puzzling diseases, such as systemic lupus erythematosus, generalized scleroderma, and probably dermatomyositis. They are characterized anatomically by systemic alterations of the connective tissue, in particular by an abnormality of its extracellular portions. This abnormality expresses itself microscopically as fibrinoid alteration and sclerosis of the collagen fibres and an increase of the metachromatic ground substance.

Such connective tissue changes alone, however, are not pathognomonic. They are observed in maladies of clearer definition, such as rheumatic fever, rheumatoid arthritis, and periarteritis nodosa. They also occur locally and can be provoked experimentally. It must, therefore, be the object of morphologic investigations to search for additional structural criteria and to evaluate their reciprocal relationship in the different diseases which involve the connective tissue. For instance the

\footnotetext{
* The Mount Sinai Hospital.
} 
recent observation of depolymerization of desoxyribose nucleic acid of mesenchymal cells in systemic lupus erythematosus introduces a new characteristic for the morphologic definition of this malady. Furthermore, it is the aim of anatomical pathology to advance beyond mere description and to inquire into the mechanism responsible for generalized connective-tissue alterations.

\section{The Protean Nature of the Connective Tissue Diseases}

\section{WALTER BAUER, J. P. KULKA and J. E. GIANSIRACUSA}

\section{Boston, Massachusetts}

In recent years there has been an increasing tendency to speak collectively of rheumatoid arthritis, rheumatic fever, lupus erythematosus disseminatus, periarteritis nodosa, dermatomyositis, and generalized scleroderma as " connective-tissue diseases". The demonstration of widespread morphological alterations in the fibrous connective tissues has led to the concept that these diseases, protean in nature, may be related. This is in sharp contrast to the traditional concept that they are clinically distinct and unrelated.

Deserving of emphasis is the fact that all these diseases have many manifestations in common. All are systemic diseases with varied constitutional, vasomotor, gastrointestinal, and articular symptoms. All may show mucocutaneous, haemorrhagic, cardiac, and neuromuscular lesions, and in all there may be generalized lymphadenopathy, serositis, alterations in leucocyte counts, and subcutaneous nodules.

Certain prominent or characteristic features are of diagnostic value. Rheumatoid arthritis is characterized by progressive, symmetrical arthritis. Ocular involvement, most often uveitis, or the presence of subcutaneous nodules may antedate the arthritis and serve as the clue to the final diagnosis. Renal disease is rare as a manifestation of this disease. In rheumatic fever cardiac involvement is the most significant manifestation. The arthritis is migratory in nature and rarely causes persistent inflammation of peri-articular structures. The presence of chorea or of erythema marginatum is presumptive evidence of rheumatic fever. A leucopenia is very unusual. The clinical picture of lupus erythematosus disseminatus is variable. The presence of a typical skin rash, serositis, arthritis, leucopenia, and renal disease in a patient with fever and other constitutional symptoms makes the diagnosis probable. The articular involvement may be indistinguishable from that seen in rheumatoid arthritis and rheumatic fever. In contradistinction to rheumatoid arthritis, spinal involvement - and advanced destruction of articular cartilage are uncommon. Skin and renal involvement may be long delayed; in the absence of both, the diagnosis is probably not warranted. Periarteritis nodosa is suggested by various combinations of the following features: renal disease, hypertension, peripheral neuritis, abdominal pain, muscle pain and tenderness, asthma, leucocytosis, and eosinophilia of impressive degree. Rarely are these features all present. Dermatomyositis, once well established, is characterized by emaciation, induration of subcutaneous tissues, marked weakness, atrophy and contractures of skeletal muscles, and frequently calcinosis. Early in the disease the clinical picture may simulate closely that of rheumatoid arthritis or lupus erythematosus disseminatus. The characteristic feature of scleroderma is the tight, waxy, adherent skin with areas of pigmentation and depigmentation. Pulmonary fibrosis, cardiac dilatation, disturbances of gastrointestinal motility, and vasomotor symptoms are other prominent manifestations.

In isolated cases, however, the clinical features considered characteristic of one or another of these diseases may overlap to such an extent that diagnosis is difficult and at times impossible. Rarely, the pathological features characteristic of two or more different diseases occur coincidentally. Thus, a patient with lupus erythematosus disseminatus showed at autopsy a necrotizing panarteritis similar to, if not identical with, periarteritis nodosa; a patient with dermatomyositis showed the lesions of both dermatomyositis and scleroderma, as well as a proliferative endarteritis and segmental necrotizing arteritis. On the other hand Aschoff bodies, lesions considered to be pathognomonic of rheumatic fever, have been seen in one typical case of periarteritis nodosa. Thus the clinician may ask the pathologist: How often is the distinction between these diseases made on a quantitative rather than a qualitative basis?

Despite the fact that these diseases usually conform to dissimilar disease patterns and differ in prognosis, the many overlapping features are noticeable. The existence of cases with pathological lesions characteristic of two or more of these diseases also suggests a relationship among them. The exact nature of this relationship with regard to aetiology and pathogenesis is unknown. It is emphasized that rigid adherence to arbitrary diagnostic criteria may obscure clues pointing to common pathogenic mechanisms. Such clues are of importance in orienting the investigative approach to these diseases.

\section{Therapeutic Criteria and Related Aids in Rheumatoid Arthritis}

\section{CORNELIUS H. TRAEGER, ROBERT C. BATTERMAN, and OTTO STEINBROCKER \\ New York}

This report summarizes recommendations for uniform therapeutic criteria in rheumatoid arthritis. A definition of rheumatoid arthritis is included, which closely follows that established by the American Rheumatism Association; this is to prevent the inclusion of doubtful cases in reporting results.

The primary considerations in undertaking the treatment of a patient with rheumatoid arthritis are: (1) to diagnose accurately; (2) to determine the stage of the disease (Table 1) ; (3) to determine the degree of functional capacity (Table 2 ).

For the purpose of evaluating the response of rheumatoid activity to any treatment, the signs of active disease presented by the patient at the initial examination 
'TABLE 1

CLASSIFICATIÓN OF RHEUMATOID PROGRESSION

\begin{tabular}{|c|c|c|c|c|c|}
\hline Stage & Radiographic signs & $\begin{array}{l}\text { Muscle } \\
\text { atrophy }\end{array}$ & $\begin{array}{l}\text { Extra-articular lesions } \\
\text { (nodules: teno-vaginitis) }\end{array}$ & Joint deformity & Ankylosis \\
\hline I & $\begin{array}{l}\text { Osteoporosis, some- } \\
\text { times no destructive } \\
\text { changes }\end{array}$ & 0 & 0 & 0 & 0 \\
\hline II & $\begin{array}{l}\text { Osteoporosis, slight } \\
\text { cartilage or subchon- } \\
\text { dral bone destruction } \\
\text { may be present }\end{array}$ & Adjacent & May be present & 0 & 0 \\
\hline III & $\begin{array}{l}\text { Osteoporosis, cartilage } \\
\text { destruction, bone } \\
\text { destruction }\end{array}$ & Extensive & May be present & $\begin{array}{l}\text { Subluxation, ulnar } \\
\text { deviation and/or } \\
\text { hyperextension }\end{array}$ & 0 \\
\hline IV & $\begin{array}{l}\text { Same as III with bony } \\
\text { ankylosis }\end{array}$ & Extensive & May be present & Same as III & $\begin{array}{l}\text { Fibrous or bony } \\
\text { ankylosis }\end{array}$ \\
\hline
\end{tabular}

TABLE 2

\section{CLASSIFICATION OF FUNCTIONAL CAPACITY}

\begin{tabular}{c|c}
\hline I & $\begin{array}{l}\text { Complete: } \\
\text { Ability to carry on all usual duties without } \\
\text { handicaps. } \\
\text { Adequate for normal activities: } \\
\text { Despite handicap of discomfort or limited } \\
\text { motion at one or more joints. } \\
\text { Limited: } \\
\text { Only to little or none of duties of usual occupa- } \\
\text { tion or self care. } \\
\text { Incapacitated, largely or wholly: } \\
\text { Bedridden or confined to wheel chair; little or } \\
\text { no self care. }\end{array}$ \\
\hline
\end{tabular}

constitute the maximum evidence of rheumatoid activity in that individual, and form the basis for determining response to therapy by decrease in those signs of activity. Such responses to therapy may be divided into four grades: I, complete remission'; II, major improvement; III, minor improvement; IV, no improvement or progression (Table 3). Whenever possible precision instruments, such as tape measure and goniometero should be used in estimating the degree of swelling an motion, for the purpose of reporting the progress of the disease under therapy.

It is urged that an arbitrary time limit be established for initial therapeutic response for each method of therapy. This is because the disease has natural fluctuation, remissions, and exacerbations. This arbitrary time limit should be long enough to exclude the

TABLE 3

RESPONSE OF RHEUMATOID ACTIVITY TO THERAPY

\begin{tabular}{|c|c|c|c|c|c|c|c|}
\hline GRADE & $\begin{array}{c}\text { Systemic } \\
\text { signs }\end{array}$ & $\begin{array}{c}\text { Signs of } \\
\text { joint } \\
\text { inflammation }\end{array}$ & $\begin{array}{l}\text { Signs of } \\
\text { extra-articular } \\
\text { activity }\end{array}$ & $\begin{array}{l}\text { Remaining } \\
\text { impairment of } \\
\text { joint mobility }\end{array}$ & $\begin{array}{l}\text { Articular } \\
\text { deformity }\end{array}$ & $\begin{array}{l}\text { Erythrocyte } \\
\text { sedimentation } \\
\text { rate }\end{array}$ & $\begin{array}{l}\text { Radiographic } \\
\text { signs }\end{array}$ \\
\hline $\begin{array}{l}\text { I } \\
\text { Complete } \\
\text { remission }\end{array}$ & 0* & $0^{*}$ & $0^{*}$ & $\begin{array}{l}\text { Due only to } \\
\text { irreversible } \\
\text { changes }\end{array}$ & $\begin{array}{l}\text { Due only to } \\
\text { irreversible } \\
\text { changes }\end{array}$ & $0^{*}$ & No progression \\
\hline $\begin{array}{l}\text { M II } \\
\text { Major } \\
\text { improve- } \\
\text { ment }\end{array}$ & $\begin{array}{l}\text { Elevated eryth- } \\
\text { rocyte sedimen- } \\
\text { tation rate and/ } \\
\text { or vasomotor } \\
\text { imbalance per- } \\
\text { missible }\end{array}$ & $\begin{array}{l}\text { Only minimum* } \\
\text { residual joint } \\
\text { swelling (no } \\
\text { new sites) }\end{array}$ & $\underset{\text { new sites) }}{\text { Minimum* (no }}$ & $\begin{array}{l}\text { Only consistent } \\
\text { with minimum } \\
\text { residual activity }\end{array}$ & $\begin{array}{l}\text { Due only to } \\
\text { irreversible } \\
\text { changes }\end{array}$ & May be elevated & No progression \\
\hline $\begin{array}{l}\text { III } \\
\text { Minor } \\
\text { improve- } \\
\text { ment }\end{array}$ & Decreased* & $\begin{array}{l}\text { Only partially* } \\
\text { resolved (no } \\
\text { new sites) }\end{array}$ & $\begin{array}{l}\text { Decreased* (no } \\
\text { new sites) }\end{array}$ & $\begin{array}{l}\text { In relation to } \\
\text { residual } \\
\text { inflammation }\end{array}$ & May be present & May be elevated & No progression \\
\hline $\begin{array}{l}\text { IV } \\
\text { Unim- } \\
\text { prove- } \\
\text { ment }\end{array}$ & Undiminished* & Same* or worse & $\begin{array}{l}\text { Same or new } \\
\text { sites or exacer- } \\
\text { bation* }\end{array}$ & $\begin{array}{l}\text { Same, better or } \\
\text { worse }\end{array}$ & Present or not & Any rate & $\begin{array}{l}\text { Changes indica- } \\
\text { tive of progrts- } \\
\text { sion }\end{array}$ \\
\hline
\end{tabular}

* Indicates criteria required to be present. 
factor of spontaneous remission. Furthermore, to avoid errors arising from misinterpretation of the natural fluctuations of the disease, it is recommended that "minor improvement" (Grade III) should not be considered significant and should not be included in any statistical survey of a therapeutic agent or procedure. This is to avoid misleading lumping of "favourable" results.

Classification of " functional impairment" together with the "criteria for therapeutic response" can give a helpful insight into the usefulness of the whole treatment programme, which may include such general procedures as physical therapy, psychotherapy, orthopaedic measures, etc., but for the purpose of evaluating a specific therapeutic agent, it is recommended that reports of such treatment should be based only on the "criteria for therapeutic response in rheumatoid activity".

\section{Heredity in Rheumatoid Arthritis and Ankylosing Spondylitis}

ROBERT M. STECHER, WALTER M. SOLOMON, and RALPH WOLPAW*

\section{Cleveland, Ohio}

The heredity and family incidence of rheumatoid arthritis, spondylitis, and rheumatic fever was studied by comparing the family histories of patients with rheumatoid arthritis and of those with spondylitis with each other and with the families of several control series. The latter consisted of 77 families of patients with Heberden's nodes, 38 families of patients with gout, and 84 other families of patients with none of these diseases. Rheumatoid arthritis occurred in the fathers, mothers, and sisters of rheumatoid patients in a significantly higher proportion than it did in the relatives of patients with spondylitis or in the controls.

Spondylitis occurred in the brothers and sisters of spondylitis patients and of rheumatoid arthritis patients more than it did in any other group. Rheumatic fever occurred much more frequently in the patients with rheumatoid arthritis and with spondylitis than in any other groups.

\section{Adrenocortical Dysfunction in Gout}

W. Q. WOLFSON, R. LEVINE, C. COHN, H. D. HUNT, H. S. GUTERMAN, and E. F. ROSENBERG

\section{Chicago}

Evidence reported suggests that androgen activity in gouty patients may be maintained by an abnormal male sex hormone which contributes only slightly to urinary 17-ketosteroid excretion. This hormone does not seem to be present in patients with non-gouty hyperuricaemia or in rheumatoid arthritis. The "gouty androgen" appears to originate in the adrenal cortex and to be

\footnotetext{
* Medical Department, Western Reserve University, City Hospital
}

secreted under conditions similar to those which control secretion of normal androgen. Gouty androgen appears to be opposed by oestrogens. Normal sex difference in plasma urate concentration may be controlled by normal androgen and gouty hyperuricaemia may be controlled by " gouty androgen".

Acute hypofunction of the adrenal cortex with respect to production of 11-oxysteroids may provide the necessary setting for an attack of gouty arthritis. This deficiency may result from endogenous metabolic changes, from increased demand for 11-oxysteroid due to stress, or withdrawal of adrenocorticotrophin.

Increased production of 11-oxysteroid compounds may terminate an attack of gouty arthritis.

Production of an abnormal androgen by the adrenal cortex and deficient response of the cortex to demánds for 11-oxysteroid are characteristic features of adrenal cortical function in gouty patients.

\section{Pleuropneumonia-like Organisms and their Possible Relation to Articular Disease}

LOUIS DIENES

Boston, Massachusetts

Organisms of the pleuropneumonia group are often recovered from the mucous membranes of humans. In animals similar organisms produce highly infectious diseases. The tendency of these organisms to localize in joints in animals producing a fleeting migratory arthritis and also ankylosing chronic arthritis is of interest in relation to the study of rheumatic diseases in humans. The pleuropneumonia group of organisms is characterized by being much smaller in size than most bacteria and by a peculiar reproductive process in which the smallest elements of the colonies become swollen into large round forms from which the small elements subsequently grow out and again repeat the cycle. This process contrasts sharply with the usual method of multiplication in bacteria namely, binary fission. The organisms are ordinarily not visible in tissues, and the diseases caused by them were in most instances regarded as virus diseases. Culture and identification are often difficult, requiring special methods. Transfer to experimental animals is usually not applicable, because pleuropneumonia organisms are specialized to one host.

It is significant that certain common bacteria, including typhoid, paratyphoid, dysentery, Proteus, Streptobacillus moniliformis, $\boldsymbol{H}$. influenzae, and saprophytic Grampositive organisms, may under appropriate conditions undergo transformation into forms indistinguishable from organisms of the pleuropneumonia group. Penicillin produces this transformation in many species of bacteria. A similar transformation has been observed in typhoid bacilli upon exposure to antibody and complement.

Although pleuropneumonia-like organisms may be recovered from the normal genital tract, they are more frequently found in association with inflammatory processes. In males, the genito-urinary infections may extend into the prostate and bladder and may be 
associated with acute articular involvement. However, the aetiological significance of pleuropneumonia-like organisms is as yet not fully understood. The unusual transformation of bacteria into a form not recognizable by the usual bacteriological methods and having different susceptibility to antibiotics raises new problems in the study of infectious diseases and may be of special interest in rheumatic diseases.

Antigenic Properties of Hyaluronidase Introduced into the Study of Rheumatic Diseases

CATHARINE E. LOGAN

Oak Park, Illinois

Intradermal injections of $1: 1,000$ hyaluronidase (0.15 TRU per $\mathrm{ml}$.) with 1 per cent. methylene blue were given to 81 individuals to determine the incidence of skin sensitivity in arthritics and controls. The results were positive in 59 of 62 patients with atrophic arthritis, in 1 of 3 patients with hypertrophic arthritis, and in 7 out of 8 patients with mixed types. Only one of the controls showed a slightly positive test.

In a number of the patients exhibiting positive tests, a cutaneous nodule developed which. lasted from three to fourteen days. Round cell infiltration, thickened and collagen fibres, small areas of necrosis, and occasional cosinophils and giant cells were seen in the several instances in which a biopsy was performed.

Twelve patients with atrophic arthritis were given a series of injections of small amounts of hyaluronidase in an attempt at desensitization. In seven of these, improvement was manifested by decrease in pain, increase in chest expansion and range of motion in the extremities, and increased strength.

Antibodies can be demonstrated in the serum. Before treatment the average titre is $1: 32$. Following the series of desensitizing injections, the titre may rise to $1: 32,768$. The skin test occasionally becomes negative after treatment.

It is concluded that sensitivity to hyaluronidase may play a part in the development of arthritic changes, in view of the tissue response at the site of injection. It is also considered possible that desensitization may alter the course of the disease.

\section{Familial Aspects of Gout \\ JOHN H. TALBOTT* \\ Buffalo, New York}

Three series of gouty patients and non-affected relatives have been studied in recent years. These researches have been pursued in Ann Arbor, Cleveland, and Boston. The fourth series is now being investigated in Buffalo. The results are similar and the tentative conclusions significant. Approximately 25 per cent. of non-affected relatives of gouty patients have a hyperuricaemia when sampled at random ages. Presumably this percentage decreases in each decade of life since an

\footnotetext{
* Buffalo General Hospital.
}

occasional non-affected relative with hyperuricaemia will develop gouty arthritis and will no longer be classified as a non-affected relative. The age at which hyperuricaemia appears has not been determined; possibly it is associated with puberty. The statistical evidence suggests that hyperuricaemia in gouty families is a single autosomal dominant gene. The mechanism whereby the dominant manifests itself is still uncertain. The strength of the dominant, that is, the degree of elevation of serum uric acid, the duration of the metabolic dyscrasia, or an as yet unrecognized factor, may all participate.

An enlightened approach to the care of gouty families would be the periodic examination of the serum of all relatives of gouty patients. These familial studies lend support to the hypothesis that the pathogenesis of gouty arthritis is related to an increased formation of uric acid by the body rather than to impaired excretion.

Role of the Anterior Pituitary and Adrenal Cortex in Urate Metabolism and in Gout

WILLIAM D. ROBINSON, JEROME W. CONN, WALTER D. BLOCK, LAWRENCE H. LOUIS, and JOSEPH KATZ

\section{Ann Arbor, Michigan}

These endocrine factors have been studied by observing (1) the effect of adrenocorticotrophic hormone on urate metabolism in normal and gouty patients and on the course of acute gout, (2) 17-ketosteroid excretion in gouty patients, (3) the effects on metabolism and clinical gout produced by stimulating the anterior pituitary with epinephrine, and (4) the effect of colchicine on the pituitary-adrenocortical mechanism. In addition to blood and urine urate determination by a specific enzymatic method, other indices of pituitary-adrenocortical activity included nitrogen balance, carbohydrate tolerance, electrolyte and water excretion, 17-ketosteroid excretion, and changes in haematology.

Adrenocorticotrophic hormone produces a marked increase in urate excretion in normal individuals without a significant fall in blood urate. The chief differences in a gouty patient given the hormone during an asymptomatic period were a sharp decrease in true blood urate to less than 50 per cent. of the base line levels, and the absence of any evidence of rebound in pituitaryadrenocortical activity in the post-injection period; acute gout developed on the third post-injection day. Acute gout following tophectomy was not associated with any evident change in adrenocortical function. Injection of the hormone resulted in prompt temporary amelioration . of symptoms on two occasions, and was followed by indications of adrenocortical stimulation.

Epinephrine in doses of $1.5 \mathrm{mg}$. intravenously had no effect on acute gout. When given to an asymptomatic gout patient intravenously, or intramuscularly in divided doses of $6 \mathrm{mg}$. daily, no metabolic effects were noted except a decrease in eosinophils. Twenty-six determinations of 17-ketosteroid excretion in ten patients with gout gave values consistently lower than normal, both during attacks and in interval periods. Colchicine, in doses of 4 to $5 \mathrm{mg}$. orally and $2.0 \mathrm{mg}$. intravenously, produced no change in eosinophil counts or nitrogen 
balance in patients with gout. Effects on blood and urine urate levels were inconstant.

Tentative conclusions to date are: (1) the adrenal cortex has a profound influence on urate metabolism, (2) its effect in gouty patients differs in some respects from that in normal subjects, (3) gout is characterized by a low excretion of 17 -ketosteroids, (4) the adrenal cortex of gouty patients can respond to stimulation, both during interval periods and at times of acute attacks. There is suggestive but not conclusive evidence that acute attacks tend to occur at times of decreased adrenocortical activity, and that the latter is the result of sluggish production or activation of endogenous adrenocorticotrophic hormone under the same conditions in which normal persons demonstrate evidence of a sharp increase in activity of endogenous adrenocorticotrophic hormone. Epinephrine appears to be an unsatisfactory method of stimulating pituitary-adrenocortical activity in gouty patients. The mode of action of colchicine through an endocrine mechanism has not been established.

\section{Fundamental Investigations on the Synovialis: an Approach to the Nature of Arthritis}

\section{I. REED, NORMAN R. JOSEPH, and IRVING E. STECK* \\ Chicago, Illinois}

A study was undertaken with new techniques of the fundamental physiology of the synovialis. Some earlier efforts had been confined to single static determinations in vitro or in vivo by means of an electrode inserted into the synovial cavity with a reference electrode inserted subcutaneously. These experiments were done continuously to allow the reaction to be followed over a long period. Another electrode inserted in the femoral vein made possible simultaneous continuous study of the changes in the blood from the general region of the joint studied. This study was of value in the evolution of procedures involving many factors integrated in varying proportions under different conditions (Amer. J. Physiol., 1946, 146, 1.)

The next step was to study the influence of vasomotor control by means of perivascular sympathectomy which produced, generally, permanent vasodilation. After stimulation of the femoral nerve the $p H$ in the vein fell transiently on the normal side, and markedly over a long period on the sympathectomized side. Massage of a normal knee joint facilitated recovery from stimulation of the nerve. On the sympathectomized side it tended to lower $p \mathrm{H}$ still further, because acidic fluid was forced from the tissues into the synovial cavity. Convulsions produced by insulin or metrazol gave rise to effects comparable to those resulting from nerve stimulation.

By this time it had become apparent that the synovial membrane is an actively metabolizing tissue. Consequently, it appeared feasible to study membrane potentials and the influences of various ions thereon (Amer. J. Physiol., 1948, 153, 364). This led directly to a study of enzyme systems. When known enzyme inhibitors or activators were injected while the potential

\footnotetext{
* University of Illinois Chicago Professional Colleges.
}

was being determined, it was possible to get a quantitative picture of the metabolic reactions occurring. In general positive millivoltage indicates a quiescent state or at least a less active state, while negative potential indicates greater activity.

Further studies are under way to determine how these facts may be integrated and modified in relation to pathological changes in the joints preliminary to arthritis.

\section{Factors Associated with the Onset of Rheumatoid Arthritis: A Statistical Study of 293 Patients and Controls}

CHARLES A. SHORT, NATHAN R. ABRAMS, and PHILIP E. SARTWELL

From Boston, Massachusetts, Cincinnati, Ohio, and Baltimore, Maryland

Results are presented from a statistical study of 293 unselected patients with rheumatoid arthritis and a similar númber of controls of corresponding age and sex. Of the patients studied, 64 per cent. were women, but this ratio was reversed in the thirty-nine patients with spinal involvement. Special localizations of other diseases show a similar change in sex ratio. The findings for the age of onset were compared with the census figures for the age distribution of the population of Massachusetts and the $\chi^{2}$ test was applied. No significant departure was found in men, but in women a marked increase was discovered in the age group 50 to 54 . An influence of the menopause is thus suggested, but these studies show no close relationship between the cessation of menstruation and the onset of the disease.

A significantly increased familial incidence of both rheumatoid arthritis and rheumatic fever was found in patients as compared with controls, but the evidence is not sufficient to establish an hereditary factor. No relationship could be shown between rheumatoid arthritis and disease of known allergic origin on the basis of familial or personal incidence of allergic manifestations. A symmetrical distribution of joint involvement was present from the onset in 70 per cent. of the 262 patients whose disease began in peripheral joints. Contrary to opinion expressed in the literature, large and small joints were primarily affected with equal frequency and those of the legs more often than those of the arms. The onset was monarticular in one-sixth of the patients, all of whom eventually suffered from polyarthritis. In one-half of the patients who had spondylitis on admission the arthritis first appeared in peripheral joints, almost invariably of the lower extremities.

The onset of definite arthritis was usually preceded by constitutional symptoms or precipitating factors or both. In the former group it was established by questioning both patients and controls that fatigue and anorexia were prodromal symptoms. Strain, either mental or physical, and acute infections most commonly preceded the onset of arthritis, with exposure to cold or dampness, surgical operations, trauma, and, infrequently, childbirth. The data suggest that prodromal constitutional symptoms may mark the real onset, and that 
so-called precipitating factors merely arise in a more easily recognizable phase, with articular localization of the morbid process.

\section{Gold Toxicology and Rheumatoid Arthritis with Particular Emphasis on Bone Marrow Studies \\ CHARLES LEROY STEINBERG \\ Rochester, New York}

One hundred and seven typical cases of rheumatoid arthritis were treated with gold thioglucose in oil. The initial dose was $40 \mathrm{mg}$., which was followed the week after by $60 \mathrm{mg}$., and then in most instances $100 \mathrm{mg}$. were given weekly intramuscularly.

A total of 154 bone marrow aspirations were done on 90 of the cases. Thirty-two patients developed skin manifestations. Four developed varying degrees of thrombocytopoenia. One developed maturation arrest of the granulocytes in the bone marrow. Ten instances of albuminuria with erythrocytes as a cause of albuminuria were noted. Two patients developed untoward gastro-intestinal symptoms, and had hyperpyrexia. Thus, fifty instances of gold toxicity were noted.

Eosinophilia of the bone marrow preceded the skin manifestations by several weeks. When the peripheral platelet count dropped, a bone marrow aspiration was done. Gold treatment could be continued in those cases in which the bone marrow was normal, but had to be stopped if megakaryocytes and platelets were scarce.

Severe instances of gold dermatitis responded well to BAL treatment. Gold treatment was not contra-indicated in those patients developing mild to moderate skin manifestations at a later date. Gold should be discontinued in patients developing suppression of the bone marrow elements. Gold treatment was not renewed in those patients who developed marked albuminuria.

Biopsy of the bone marrow should be done as a routine in patients receiving gold treatment.

\section{Résumé}

Le Septième Congrès International des Maladies Rhumatismales s'est tenu à New York du 30 mai au 3 juin 1949. On trouvera ci-dessus les résumés des plus importants articles lus au Congrès. Malheureusement, le manque de place ne nous permet pas de publier leur traduction française, mais pour référence nous indiquons ici leurs titres français.
Histopathologie des tissus conjonctifs.

Distinction pathologique entre l'ostéo-arthrite et l'ostéophytose vertébrale.

Diagnostic de l'ostéo-arthrite.

Histopathologie du système neuromusculaire dans l'arthrite rhumatismale.

Génèse périphérique de la douleur.

Maladies dues au surmenage et à l'usure du muscle strié.

\section{Titres}

Effet du $\Delta$-5-pregnalone sur l'excretion urinaire des 17-cétostéroides et la symptomatologie de la spondylite ankylosante.

Oestrogènes synthétiques dans le traitement de la spondylite ankylosante.

Membrane synoviale dans l'ostéoarthrite.

Etendue des réactions pathologiques pouvant se produire dans les tissus synoviaux humains.

Altérations histologiques et chimiques dans les muscles des malades rhumatiques et non-rhumatiques.

Valeur thérapeutique des sels du cuivre dans l'arthrite rhumatismale.

Effet des sécrétions endocrines sur les tissus articulaires et leur rapport aux processus de vieillir.

Etudes sur le probable rapport entre la fonction adréno-pituitaire et l'arthrite.

Polyarthrite chronique et le psoriasis. Opération de résection-angulation dans l'arthrite de la hanche.

Anatomie pathologique des malades collagènes.

Nature protéique des maladies du tissu conjonctif.

Critères thérapeutiques et aides associées dans l'arthrite rhumatismale.

Hérédité dans l'arthrite rhumatismale et dans la spondylite ankylosante.

Troubles de la fonction adrénocorticale dans la goutte.

Micro-organismes similaires à ceux de la pleuro-pneumonie et leur possible rapport avec la maladie articulaire.

Propriétés antigéniques de la hyaluronidase appliquées à l'étude des maladies rhumatismales.

Aspect familial de la goutte.

Rôle de l'hypophyse antérieur et de la cortico-surrénale dans le métabolisme des urates et dans la goutte. synoviale; une approche à la nature de l'arthrite.

Facteurs assóciés au début de d'arthrite rhumatismale : étude statistique de 293 malades et - témoins.

Toxicologie de l'or et l'arthrite rhumatismale, avec accent particculier sur l'étude de la moelle osseuse.
Investigation fondamentale de la
R. A. Davison et

P. Koetz.

F. Coste et $\mathrm{S}$. Bonfils.

R. E. Ghormley et

J. R. Bateman.

D. H. Collins.

J. J. Bunim et coll.

J. Forestier et coll.

M. and R. Silberberg.

G. W. Thorn et coll.

P. Barcelo et coll.

H. Milch.

P. Klemperer.

W. Bauer et coll.

C. H. Traeger.

R. M. Stecher et coll.

W. Q. Wolfson et coll.

L. Dienes.

C. E. Logan.

J. H. Talbot.

W. D. Robinson et coll.

C. E. Reed et coll.

C. A. Short et coll.

et coll.

J. H. Kellgren.

H. Seyfarth and

K. Møinichen. 